\title{
A new twist in neuroendocrine tumor research: Pacak-Zhuang syndrome, HIF-2a as the major player in its pathogenesis and future therapeutic options
}

\author{
Ivana Jochmanova, Ivica Lazurova
}

\begin{abstract}
Backround. There is increasing evidence of the role of hypoxia or pseudohypoxia in tumorigenesis, including pheochromocytoma (PHEO) and paraganglioma (PGL). (Pseudo)hypoxia leads to activation of hypoxia-inducible transcription factors (HIFs) and thus, promotes the transcription of hypoxia-responsive genes which are involved in tumorigenesis. Recently identified is a new syndrome consisting of multiple and recurrent PGLs or PHEOs, somatostatinoma, and congenital polycythemia, due to somatic hypoxia-inducible factor 2 a gene (HIF2A) mutations.

Methods and Results. PubMed and Web of Science online databases were used to search reviews and original articles on the HIF, PHEO/PGL, and Pacak-Zhuang syndrome.

Conclusions. The novel somatic and germline gain-of-function HIF $2 A$ mutations described latterly emphasize the role of the HIF-2a in the PHEO/PGL development and these findings designate HIF, especially HIF-2a, as a promising treatment target.
\end{abstract}

Key words: hypoxia-inducible factor, tumorigenesis, pheochromocytoma, paraganglioma, Pacak-Zhuang syndrome

Received: December 10, 2013; Accepted: April 15, 2014; Available online: April 29, 2014

http://dx.doi.org/10.5507//bp.2014.021

$1^{\text {st }}$ Department of Internal Medicine, Medical Faculty, P.J. Safarik University, Trieda SNP 1, 04011, Kosice, Slovak Republic Corresponding author: Ivana Jochmanova, e-mail: ivana.jochmanova@gmail.com

\section{INTRODUCTION}

The last few years have provided novel information about the pathogenesis of neuroendocrine tumors (NETs), especially pheochromocytoma (PHEO) and paraganglioma (PGL). PHEOs are catecholamine-producing neuroendocrine tumors derived from the chromaffin cells of the adrenal medulla ${ }^{1}$ and PGLs are tumors arising from extra-adrenal chromaffin tissues ${ }^{2}$. PHEOs and PGLs share overlapping characteristics (histopathology, molecular pathobiology) but there are also many differences in terms of their behavior, aggressiveness, metastatic potential, etc. PHEOs and PGLs can occur as sporadic tumors or as a component of hereditary tumor syndromes, including multiple endocrine neoplasia syndromes (MEN2A and MEN2B), von Hippel-Lindau disease (VHL), and neurofibromatosis type 1 (NF1) resulting, respectively, from mutations of RET (Rearranged in Transfection) protooncogene, VHL tumor suppressor gene $(V H L)$, or the NF1 tumor suppressor gene ${ }^{3-7}$. The other known PHEO susceptibility genes are germline mutations in succinate dehydrogenase subunits (SDHx): SDHB, SDHC, SDHD and SDHAF2 (also known as SDH5). Following identification of their loci familial paraganglioma they were classified into the four groups, PGL4, PGL3, PGL1 and PGL2 (ref. ${ }^{5,8-12}$ ). The study of PHEO/PGL familial syndromes is a cornerstone in understanding the pathogenic mechanisms involved in the development of these tumors. In the last five years, excellent pioneering studies have identified new genetic candidates that have been found to predispose to the development of PHEO and PGL: SDHA $\left(\right.$ ref. ${ }^{13}$ ), transmembrane protein 127 (TMEM127) $\left(\right.$ ref. $\left.{ }^{14,15}\right)$, Myc-associated factor X (MAX) $\left(\right.$ ref. $\left.^{16}\right)$, kinesin family member $1 \mathrm{~B}$, transcript variant beta (KIF1B $\beta$ ) (ref. ${ }^{17}$ ), prolyl hydroxylase domain 2 (PHD2) (ref. ${ }^{18}$ ), and recently hypoxia-inducible factor $2 \alpha$ (HIF-2 $\alpha$ ) (ref. ${ }^{19}$ ) genes. Currently gene mutations can be identified in more than one third of PHEOs/PGLs $\left(\right.$ ref. $^{20}$ ). It is obvious that in last five years important progress was made in the understanding of the pathophysiology of PHEO/ PGL due to the discovery of these new genes and their involvement in PHEO/PGL development. Moreover, a new unique syndrome type disease carrying PHEO/ PGL-somatostatinoma-polycythemia, also named the Pacak-Zhuang syndrome with the hypoxia sensing domain mutations at HIF $2 A$ has substantially improved our understanding of a critical molecular mechanism in PHEOs/PGLs ${ }^{21}$. This finding for the first time indicated that $\mathrm{HIF} \alpha$ protein with its regulatory elements is a central player in the pathogenesis of PHEOs/PGLs with various genetic causes ${ }^{22}$.

\section{HIF-2A AND TUMORIGENESIS}

HIF transcription factors mediate adaptive responses of cells to hypoxia or pseudohypoxia ${ }^{23-26}$. HIFs form heterodimeric complexes comprising an oxygen-sensitive $\alpha$ subunit and a stable $\beta$ subunit. The HIF $\alpha$-subunit is ubiquitously expressed and consists of three isoforms, HIF-1 $\alpha$, HIF- $2 \alpha$, and HIF- $3 \alpha$ (ref. ${ }^{24,25}$ ). The HIF $\beta$ subunit is constitutively expressed ${ }^{27}$. Heterodimers of HIFs bind to the promoter of multiple genes associated with angiogenesis, glycolysis, and cell growth. 
Under normoxic conditions, HIF-1 $\alpha$ and HIF-2 $\alpha$ are degraded via the ubiquitin-proteasome pathway. This degradation is controlled mostly by the hydroxylation of the two specific prolyl residues by prolyl hydroxylase domain proteins (PHDs - PHD1, PHD2, and PHD3) $\left(\right.$ ref. $\left.^{24,25}\right)$. This hydroxylation is crucial for recognition of HIF- $1 \alpha$ and HIF- $2 \alpha$ by the VHL protein (pVHL) (ref. ${ }^{28}$ ) and subsequent proteasomal degradation ${ }^{25}$. The negative regulation of HIF is mediated via the inhibitory PAS domain protein (IPAS), which is the HIF-3 $\alpha 2$ splice variant. IPAS forms inactive complexes with HIF- $1 \alpha$ and thus, it is a negative regulator of HIF-1 $\alpha$ (ref. $\left.{ }^{29-31}\right)$. The other HIF- $1 \alpha$ inhibitor is factor-inhibiting HIF-1 $\alpha$ (FIH1) which hydroxylates HIF-1 $\alpha$ and blocks its interaction with the coactivators $^{32}$ and thus inhibits the transactivation of HIF target genes.

Under hypoxic or pseudohypoxic conditions, HIF $\alpha$ becomes stabilized, forms hererodimers with HIF $\beta$, recruits coactivators and binds to the core DNA at hypoxiaresponsive elements (HREs) in target genes and activates their transcription ${ }^{25,33,34}$. Short periods of severe hypoxia lead to HIF- $1 \alpha$ activation, whereas HIF- $2 \alpha$ is activated under mild or prolonged hypoxia ${ }^{35}$. Different regulation of HIF- $1 \alpha$ and HIF- $2 \alpha$ is mediated by hypoxia associated factor (HAF) and this difference leads to distinct cellular functions ${ }^{36}$. For a review, see Richter et al. ${ }^{37}$. The HIF target genes include genes involved in angiogenesis, glucose metabolism, extracellular matrix formation, cell proliferation and survival, $\mathrm{pH}$ regulation, epithelial to mesenchymal transition, red blood cell production and iron metabolism and many others ${ }^{38-43}$. Many of these genes are involved in cancer development, progression, and metastasis. HIF $\alpha$ expression or stabilization can also be regulated by mechanisms other than hypoxia, including growth factors signaling pathway and a loss of tumor suppressor genes ${ }^{44}$. This allows crosstalk between different signaling pathways resulting in cell transformation and tumor development ${ }^{25,45,46}$.

Deregulation of HIF $\alpha$ has long been implicated in tumorigenesis since there is an interaction of HIF with many pivotal signaling pathways and (pseudo)hypoxia is found in almost all cancers ${ }^{25,34,46-49}$. Both HIF-1 $\alpha$ and HIF- $2 \alpha$ seem to act as master regulators in adaptation of cancer progenitor/stem cells and their differentiated progenies to oxygen and nutrient deprivation (for a review, see Mimeault et al. ${ }^{50}$ ). HIF- $1 \alpha$ and HIF-2 $\alpha$ were found to be overexpressed in almost all human cancers. HIF- $2 \alpha$ is mostly overexpressed in advanced lesions and is associated with poor prognosis ${ }^{51-54}$. Moreover, HIF-2 $\alpha$ has been shown to regulate HIF-1 $\alpha$ target gene expression in the absence of HIF- $1 \alpha$ and vice versa ${ }^{55,56}$, reviewed by Keith et al. ${ }^{26}$

HIF- $2 \alpha$ has also been proposed as a tumor suppressor in Kras-driven lung tumor mouse model, since HIF2A deletion leads to tumor growth and progression ${ }^{57}$. But the overexpression of HIF- $2 \alpha$ in the same mouse model was associated with increased tumor formation ${ }^{58}$. These findings suggest that both HIF- $2 \alpha$ upregulation and downregulation can promote tumor formation and progression and that a balance of HIF- $2 \alpha$ production is needed for its proper function.
In renal cell carcinoma (RCC) decreased HIF $\alpha$ degradation was observed due to VHL mutations and HIF- $2 \alpha$ inhibition was shown to be sufficient to suppress tumor growth $^{59,60}$. It was also shown that protumorigenic genes encoding vascular endothelial growth factor (VEGF), cyclin $\mathrm{D}$, and transforming growth factor $\alpha(\mathrm{TGF} \alpha)$, are predominantly regulated by HIF- $2 \alpha$, while proapoptotic gene encoding BNip3 responds to HIF-1 $\alpha$ in RCC (ref. ${ }^{61}$ ).

HIF- $2 \alpha$ also plays an important role in angiogenesis, hematopoiesis and iron metabolism. Under hypoxic conditions HIF- $2 \alpha$ is able to induce the expression of angiogenesis related genes (e.g. VEGF) in endothelial cells ${ }^{62}$. HIF- $2 \alpha$ regulates erythropoietin expression and thus, is critical for hemopoiesis ${ }^{55,63-65}$. HIF-2 $\alpha$ was shown to play a crucial role in maintaining of iron balance by the regulation of iron absorption in the intestine ${ }^{66}$ and HIF signaling may contribute to altered iron metabolism in cancer ${ }^{67}$.

The other tumorigenic processes, such as cell migration, matrix vascular remodeling, invasion are also affected by HIF- $2 \alpha$ upregulation, and in process of tumorigenesis the stromal microenvironment plays also an important role. Further information can be found in references ${ }^{37,51,68-72}$.

\section{HIF2A MUTATIONS IN PACAK-ZHUANG SYNDROME AS WELL AS IN SPORADIC PHEO/PGL}

In the first report, novel somatic gain-of-function HIF2A mutations in two patients with polycythemia and multiple PGLs with duodenal somatostatinomas (in $2^{\text {nd }}$ patient somatostatinoma was identified after the report was published) were identified by Zhuang et al. ${ }^{19}$. Later on the same group and other investigators found somatic HIF $2 A$ mutations in patients with PGL/PHEO with and without association with polycythemia and somatostatino$\mathrm{ma}^{21,73,74}$. The association of congenital polycythemia with two distinct types of NETs - PGL/PHEO and duodenal somatostatinoma found world-wide, strongly indicated the existence of a unique disease cluster that shared same gene mutation. This was reported as a new syndrome (PacakZhuang syndrome) (ref. ${ }^{21}$ ). Subsequently, a novel germline HIF $2 A$ mutation in a patient with congenital polycythemia with multiple PGLs was described by Lorenzo et al. ${ }^{75}$ and more patients presenting with $H I F 2 A$ mutations and PGLs/PHEOs with or without polycythemia were reported $^{76-79}$. Based on the multiple organs and multiple and distant tumor sites involved in a same patient, one could speculate that the mutation in HIF2A must occur in early life or during embryogenesis similar to the McCuneAlbright syndrome. It is interesting to point out that this syndrome has been so far found mostly in female patients.

It has been shown that HIF plays an important role in neural crest development and differentiation, and in the function of adrenal medulla and paraganglia. HIF- $1 \alpha$ is essential in the development of neural tube and cardiovascular system and high HIF-2 $\alpha$ expression was observed in developing paraganglia and HIF-2 $\alpha$ is necessary for catecholamine synthesis ${ }^{80-82}$, reviewed in Richter et al. ${ }^{37}$. 
HIF- $2 \alpha$ is also considered the key regulator of erythropoiesis and this association has been demonstrated initially in four patients with polycythemia who were found to have activating germline $H I F 2 A$ mutations ${ }^{83}$. HIF-2 $\alpha$ stabilization and PGL-associated EPO production have been also found in patients with $P H D 2$ and $V H L$ mutations ${ }^{84,85}$.

$H I F 2 A$ gain-of-function mutations in patients with the Pacak-Zhuang syndrome lead to reduced HIF- $2 \alpha$ hydroxylation and binding to the pVHL resulting in 4-6 times higher stability of mutant HIF- $2 \alpha$ compared to a wild-type $^{19,21}$. The clinical presentations of patients were consistent with HIF- $2 \alpha$ dysregulation. PGLs are found to have a typical noradrenergic biochemical phenotype, which reflects the involvement of HIF- $2 \alpha$ in the preferential norepinephrine synthesis ${ }^{80,82,86}$ and the strong positive immunohistochemical staining for HIF- $2 \alpha$ in patient's tumor tissues and increased tumor mRNA for HIF- $2 \alpha$ downstream genes indicate HIF $2 \alpha$ upregulation.

Interestingly, all patients with polycythemia were diagnosed with PGL or PHEO at a young age, especially under 35 , but patients without polycythemia presented with PHEO/PGL later and mostly without multifocal disease. These findings suggest the different timing during gestation when somatic HIF2A mutations occur, may affect the phenotypes of the syndrome in these patients ${ }^{37}$. It cannot be excluded that in those patients not presenting with a polycythemia despite having $H I F 2 A$ mutations such a somatic mutation occurred later on in the fetus development. The degree of hypoxia and microenvironmental changes, including nutrition, may also play an important role.

The HIF pathway has been found to be disrupted in some PHEOs and PGLs ${ }^{8,25,87-95}$, depending on their genetic background and contributing to their development, recently reviewed by Jochmanova et al. ${ }^{22}$ and Richter et al. ${ }^{37}$.

\section{CONCLUSIONS AND FUTURE THERAPEUTIC OPTIONS}

The finding of the Pacak-Zhuang syndrome led to an important discovery of HIF-2 $\alpha$ mutation in PHEO/PGL. HIF- $2 \alpha$ signaling pathway appears to play one of the most important roles in PHEO/PGL pathogenesis and other cancers development and this designates HIF- $2 \alpha$ as an attractive and promising therapeutic target. The most promising therapeutic strategies are HIF pathway targeted therapies, especially on HIF- $2 \alpha$ inhibition. Currently, there are several agents affecting the HIF-1 $\alpha$ signaling ${ }^{96}$ (for a review, see Mellilo et al. ${ }^{97,98}$ ). Drugs selectively targeting HIF- $2 \alpha$ signaling have not been fully developed yet but are under investigation ${ }^{99,100}$. Moreover, it has been shown that HIF- $1 \alpha$ and HIF- $2 \alpha$ can activate target genes alternatively $^{26,56}$, thus development of drugs targeting both HIF- $1 \alpha$ and HIF- $2 \alpha$ is of a great interest. Another therapeutic approach could be changing the balance of HIF $\alpha$ isoforms by modulating HAF signaling in tumors, since it was shown that HAF switches cells from HIF-1 $\alpha$ to HIF-2 $\alpha$ signaling ${ }^{36}$. Further investigations are needed to elucidate the other signaling pathways involved in PHEO/
PGL development and crosstalk within these pathways and HIF signaling pathway.

Finding novel diagnostic biomarkers associated with hypoxia and altered metabolic pathways should help to select patients who are likely to respond to a specific type of therapy (e.g. to the HIF signaling inhibitors) for personalized anti-cancer treatment. Based on this, multi-targeted therapeutic approaches, which should be more effective, can be used in PHEO/PGL treatment.

Furthermore, it is of a great interest to find out whether females found in Pacak-Zhuang syndrome are exclusively affected and if so, what pathogenic mechanism is involved in this sex selected process. In addition, erythropoietin is elevated in tumor tissue, however, it is not clear how this elevation occurs in early life and from which additional tissues, except tumor tissue, erythropoietin is derived from. Finally, it would be of interest to further study these patients whether they develop metastatic disease, other types of neuroendocrine and/or other abnormalities as the syndrome has been just discovered and more studies are needed to fully understand this disease.

\section{AUTHORSHIP CONTRIBUTIONS}

IJ: Literature search, data analysis and interpretation, manuscript writing; IL: Conception and design, critical revision of the manuscript.

\section{CONFLICT OF INTEREST STATEMENT}

The authors state that there are no conflicts of interest regarding the publication of this article.

\section{REFERENCES}

1. DeLellis RA, Lloyd RV, Heitz PU, Eng C. Tumours of Endocrine Organs. Lyon: IARC Press; 2004.

2. Whalen RK, Althausen AF, Daniels GH. Extra-adrenal pheochromocytoma. J Urol 1992;147(1):1-10.

3. Brannan Cl, Perkins AS, Vogel KS, Ratner N, Nordlund ML, Reid SW, Buchberg AM, Jenkins NA, Parada LF, Copeland NG. Targeted disruption of the neurofibromatosis type-1 gene leads to developmental abnormalities in heart and various neural crest-derived tissues. Genes Dev 1994;8(9):1019-29.

4. Shen MH, Harper PS, Upadhyaya M. Molecular genetics of neurofibromatosis type 1 (NF1). J Med Genet 1996;33(1):2-17.

5. Bryant J, Farmer J, Kessler LJ, Townsend RR, Nathanson KL. Pheochromocytoma: the expanding genetic differential diagnosis. J Natl Cancer Inst 2003;95(16):1196-204.

6. Eisenhofer G, Bornstein SR, Brouwers FM, Cheung NK, Dahia PL, de Krijger RR, Giordano TJ, Greene LA, Goldstein DS, Lehnert H, Manger WM, Maris JM, Neumann HP, Pacak K, Shulkin BL, Smith DI, Tischler AS, Young WF, Jr. Malignant pheochromocytoma: current status and initiatives for future progress. Endocr Relat Cancer 2004;11(3):42336.

7. Tischler AS. Pheochromocytoma and extra-adrenal paraganglioma: updates. Arch Pathol Lab Med 2008;132(8):1272-84.

8. Baysal BE, Ferrell RE, Willett-Brozick JE, Lawrence EC, Myssiorek D, Bosch A, van der Mey A, Taschner PE, Rubinstein WS, Myers EN, Richard CW, 3rd, Cornelisse CJ, Devilee P, Devlin B. Mutations in SDHD, a mitochondrial complex II gene, in hereditary paraganglioma. Science 2000;287(5454):848-51. 
9. Niemann S, Muller U. Mutations in SDHC cause autosomal dominant paraganglioma, type 3. Nat Genet 2000;26(3):268-70.

10. Astuti D, Douglas F, Lennard TW, Aligianis IA, Woodward ER, Evans DG, Eng C, Latif F, Maher ER. Germline SDHD mutation in familial phaeochromocytoma. Lancet 2001;357(9263):1181-2.

11. Baysal BE, Willett-Brozick JE, Lawrence EC, Drovdlic CM, Savul SA, McLeod DR, Yee HA, Brackmann DE, Slattery WH, 3rd, Myers EN, Ferrell RE, Rubinstein WS. Prevalence of SDHB, SDHC, and SDHD germline mutations in clinic patients with head and neck paragangliomas. J Med Genet 2002;39(3):178-83.

12. Amar L, Bertherat J, Baudin E, Ajzenberg C, Bressac-de Paillerets B, Chabre O, Chamontin B, Delemer B, Giraud S, Murat A, NiccoliSire P, Richard S, Rohmer V, Sadoul JL, Strompf L, Schlumberger M, Bertagna X, Plouin PF, Jeunemaitre X, Gimenez-Roqueplo AP. Genetic testing in pheochromocytoma or functional paraganglioma. J Clin Oncol 2005;23(34):8812-8.

13. Burnichon N, Briere JJ, Libe R, Vescovo L, Riviere J, Tissier F, Jouanno E, Jeunemaitre X, Benit P, Tzagoloff A, Rustin P, Bertherat J, Favier J, Gimenez-Roqueplo AP. SDHA is a tumor suppressor gene causing paraganglioma. Hum Mol Genet 2010;19(15):3011-20.

14. Qin Y, Yao L, King EE, Buddavarapu K, Lenci RE, Chocron ES, Lechleiter JD, Sass M, Aronin N, Schiavi F, Boaretto F, Opocher G, Toledo RA, Toledo SP, Stiles C, Aguiar RC, Dahia PL. Germline mutations in TMEM127 confer susceptibility to pheochromocytoma. Nat Genet 2010;42(3):229-33.

15. Jiang S, Dahia PL. Minireview: the busy road to pheochromocytomas and paragangliomas has a new member, TMEM127. Endocrinology 2011;152(6):2133-40.

16. Comino-Mendez I, Gracia-Aznarez FJ, Schiavi F, Landa I, LeandroGarcia LJ, Leton R, Honrado E, Ramos-Medina R, Caronia D, Pita G, Gomez-Grana A, de Cubas AA, Inglada-Perez L, Maliszewska A Taschin E, Bobisse S, Pica G, Loli P, Hernandez-Lavado R, Diaz JA, Gomez-Morales M, Gonzalez-Neira A, Roncador G, RodriguezAntona C, Benitez J, Mannelli M, Opocher G, Robledo M, Cascon A. Exome sequencing identifies MAX mutations as a cause of hereditary pheochromocytoma. Nat Genet 2011;43(7):663-7.

17. Schlisio S, Kenchappa RS, Vredeveld LC, George RE, Stewart R, Greulich H, Shahriari K, Nguyen NV, Pigny P, Dahia PL, Pomeroy SL, Maris JM, Look AT, Meyerson M, Peeper DS, Carter BD, Kaelin WG, Jr. The kinesin KIF1Bbeta acts downstream from EgIN3 to induce apoptosis and is a potential 1 p36 tumor suppressor. Genes Dev 2008;22(7):884-93.

18. Astuti D, Ricketts CJ, Chowdhury R, McDonough MA, Gentle D, Kirby G, Schlisio S, Kenchappa RS, Carter BD, Kaelin WG, Jr., Ratcliffe PJ, Schofield CJ, Latif F, Maher ER. Mutation analysis of HIF prolyl hydroxylases (PHD/EGLN) in individuals with features of phaeochromocytoma and renal cell carcinoma susceptibility. Endocr Relat Cancer 2011;18(1):73-83

19. Zhuang Z, Yang C, Lorenzo F, Merino M, Fojo T, Kebebew E, Popovic V, Stratakis CA, Prchal JT, Pacak K. Somatic HIF2A gain-of-function mutations in paraganglioma with polycythemia. N Engl J Med 2012;367(10):922-30.

20. Jafri M, Maher ER. The genetics of phaeochromocytoma: using clinical features to guide genetic testing. Eur J Endocrino 2012;166(2):151-8

21. Pacak K, Jochmanova I, Prodanov T, Yang C, Merino MJ, Fojo T, Prchal JT, Tischler AS, Lechan RM, Zhuang Z. New syndrome of paraganglioma and somatostatinoma associated with polycythemia. J Clin Oncol 2013;31(13):1690-8.

22. Jochmanova I, Yang C, Zhuang Z, Pacak K. Hypoxia-inducible factor signaling in pheochromocytoma: turning the rudder in the right direction. J Natl Cancer Inst 2013;105(17):1270-83.

23. Semenza GL. Oxygen sensing, homeostasis, and disease. N Engl J Med 2011;365(6):537-47.

24. Schofield CJ, Ratcliffe PJ. Oxygen sensing by HIF hydroxylases. Nat Rev Mol Cell Biol 2004;5(5):343-54.

25. Kaelin WG, Jr., Ratcliffe PJ. Oxygen sensing by metazoans: the central role of the HIF hydroxylase pathway. Mol Cell 2008;30(4):393-402.

26. Keith B, Johnson RS, Simon MC. HIF1alpha and HIF2alpha: sibling rivalry in hypoxic tumour growth and progression. Nat Rev Cancer 2012;12(1):9-22.

27. Wang GL, Jiang BH, Rue EA, Semenza GL. Hypoxia-inducible factor 1 is a basic-helix-loop-helix-PAS heterodimer regulated by cellular O2 tension. Proc Natl Acad Sci U S A 1995;92(12):5510-4.

28. Hon WC, Wilson MI, Harlos K, Claridge TD, Schofield CJ, Pugh CW, Maxwell PH, Ratcliffe PJ, Stuart DI, Jones EY. Structural basis for the recognition of hydroxyproline in HIF-1 alpha by pVHL. Nature 2002:417(6892):975-8.

29. Heikkila M, Pasanen A, Kivirikko KI, Myllyharju J. Roles of the human hypoxia-inducible factor (HIF)-3alpha variants in the hypoxia response. Cell Mol Life Sci 2011;68(23):3885-901.

30. Makino Y, Cao R, Svensson K, Bertilsson G, Asman M, Tanaka H, Cao $Y$, Berkenstam A, Poellinger L. Inhibitory PAS domain protein is a negative regulator of hypoxia-inducible gene expression. Nature 2001;414(6863):550-4.

31. Jang MS, Park JE, Lee JA, Park SG, Myung PK, Lee DH, Park BC, Cho S. Binding and regulation of hypoxia-inducible factor- 1 by the inhibitory PAS proteins. Biochem Biophys Res Commun 2005;337(1):20915 .

32. Lando D, Peet DJ, Gorman JJ, Whelan DA, Whitelaw ML, Bruick RK $\mathrm{FIH}-1$ is an asparaginyl hydroxylase enzyme that regulates the transcriptional activity of hypoxia-inducible factor. Genes Dev 2002;16(12):1466-71.

33. Lau KW, Tian YM, Raval RR, Ratcliffe PJ, Pugh CW. Target gene selectivity of hypoxia-inducible factor-alpha in renal cancer cells is conveyed by post-DNA-binding mechanisms. Br J Cancer 2007;96(8):1284-92.

34. Maxwell PH, Pugh CW, Ratcliffe PJ. Activation of the HIF pathway in cancer. Curr Opin Genet Dev 2001;11(3):293-9.

35. Holmquist-Mengelbier L, Fredlund E, Lofstedt T, Noguera R, Navarro S, Nilsson H, Pietras A, Vallon-Christersson J, Borg A, Gradin K, Poellinger L, Pahlman S. Recruitment of HIF-1alpha and HIF-2alpha to common target genes is differentially regulated in neuroblastoma: HIF-2alpha promotes an aggressive phenotype. Cancer Cell 2006;10(5):413-23.

36. Koh MY, Lemos R, Jr., Liu X, Powis G. The hypoxia-associated factor switches cells from HIF-1alpha- to HIF-2alpha-dependent signaling promoting stem cell characteristics, aggressive tumor growth and invasion. Cancer Res 2011;71(11):4015-27.

37. Richter S, Qin N, Pacak K, Eisenhofer G. Role of hypoxia and HIF2alpha in development of the sympathoadrenal cell lineage and chromaffin cell tumors with distinct catecholamine phenotypic features. Adv Pharmacol 2013;68:285-317.

38. Semenza GL. Targeting HIF-1 for cancer therapy. Nat Rev Cancer 2003;3(10):721-32.

39. Petrella BL, Lohi J, Brinckerhoff CE. Identification of membrane type-1 matrix metalloproteinase as a target of hypoxia-inducible factor- 2 alpha in von Hippel-Lindau renal cell carcinoma. Oncogene 2005;24(6):1043-52.

40. Zagzag D, Krishnamachary B, Yee H, Okuyama H, Chiriboga L, Ali MA, Melamed J, Semenza GL. Stromal cell-derived factor-1alpha and CXCR4 expression in hemangioblastoma and clear cell-renal cell carcinoma: von Hippel-Lindau loss-of-function induces expression of a ligand and its receptor. Cancer Res 2005;65(14):6178-88.

41. Erler JT, Bennewith KL, Nicolau M, Dornhofer N, Kong C, Le QT, Chi JT, Jeffrey SS, Giaccia AJ. Lysyl oxidase is essential for hypoxia-induced metastasis. Nature 2006;440(7088):1222-6.

42. Bertout JA, Patel SA, Simon MC. The impact of $\mathrm{O} 2$ availability on human cancer. Nat Rev Cancer 2008:8(12):967-75.

43. Miyata T, Takizawa S, van Ypersele de Strihou C. Hypoxia. 1. Intracellular sensors for oxygen and oxidative stress: novel therapeutic targets. Am J Physiol Cell Physiol 2011;300(2):C226-31.

44. Bardos Jl, Ashcroft M. Negative and positive regulation of HIF-1: a complex network. Biochim Biophys Acta 2005;1755(2):107-20.

45. Pouyssegur J, Dayan F, Mazure NM. Hypoxia signalling in cancer and approaches to enforce tumour regression. Nature 2006:441(7092):437-43.

46. Semenza GL. Defining the role of hypoxia-inducible factor 1 in cancer biology and therapeutics. Oncogene 2010;29(5):625-34.

47. Semenza GL. Involvement of hypoxia-inducible factor 1 in human cancer. Intern Med 2002;41(2):79-83.

48. Kaelin WG, Jr. The von Hippel-Lindau gene, kidney cancer, and oxygen sensing. J Am Soc Nephrol 2003;14(11):2703-11.

49. Mucaj V, Shay JE, Simon MC. Effects of hypoxia and HIFs on cancer metabolism. Int J Hematol 2012;95(5):464-70.

50. Mimeault M, Batra SK. Hypoxia-inducing factors as master regulators of stemness properties and altered metabolism of cancer- and metastasis-initiating cells. J Cell Mol Med 2013;17(1):30-54.

51. Talks KL, Turley H, Gatter KC, Maxwell PH, Pugh CW, Ratcliffe PJ, Harris AL. The expression and distribution of the hypoxia-inducible factors HIF-1alpha and HIF-2alpha in normal human tissues, cancers, and tumor-associated macrophages. Am J Pathol 2000;157(2):411-21. 
52. Hockel M, Vaupel P. Biological consequences of tumor hypoxia. Semin Oncol 2001;28(2 Suppl 8):36-41.

53. Harris AL. Hypoxia--a key regulatory factor in tumour growth. Nat Rev Cancer 2002;2(1):38-47.

54. Qing G, Simon MC. Hypoxia inducible factor-2alpha: a critical mediator of aggressive tumor phenotypes. Curr Opin Genet Dev 2009;19(1):60-6.

55. Warnecke C, Zaborowska Z, Kurreck J, Erdmann VA, Frei U, Wiesener $M$, Eckardt KU. Differentiating the functional role of hypoxia-inducible factor (HIF)-1alpha and HIF-2alpha (EPAS-1) by the use of RNA interference: erythropoietin is a HIF-2alpha target gene in Hep3B and Kelly cells. FASEB J 2004;18(12):1462-4.

56. Koh MY, Powis G. Passing the baton: the HIF switch. Trends Biochem Sci 2012;37(9):364-72.

57. Mazumdar J, Hickey MM, Pant DK, Durham AC, Sweet-Cordero A Vachani A, Jacks T, Chodosh LA, Kissil JL, Simon MC, Keith B. HIF2alpha deletion promotes Kras-driven lung tumor development. Proc Natl Acad Sci U S A 2010;107(32):14182-7.

58. Kim WY, Perera S, Zhou B, Carretero J, Yeh JJ, Heathcote SA, Jackson AL, Nikolinakos P, Ospina B, Naumov G, Brandstetter KA, Weigman VJ, Zaghlul S, Hayes DN, Padera RF, Heymach JV, Kung AL, Sharpless NE, Kaelin WG, Jr., Wong KK. HIF2alpha cooperates with RAS to promote lung tumorigenesis in mice. J Clin Invest 2009;119(8):2160-70.

59. Kondo K, KIco J, Nakamura E, Lechpammer M, Kaelin WG, Jr. Inhibition of HIF is necessary for tumor suppression by the von Hippel-Lindau protein. Cancer Cell 2002;1(3):237-46.

60. Kondo K, Kim WY, Lechpammer M, Kaelin WG, Jr. Inhibition of HIF2alpha is sufficient to suppress PVHL-defective tumor growth. PLoS Biol 2003;1(3):E83.

61. Raval RR, Lau KW, Tran MG, Sowter HM, Mandriota SJ, Li JL, Pugh CW, Maxwell PH, Harris AL, Ratcliffe PJ. Contrasting properties of hypoxia-inducible factor 1 (HIF-1) and HIF-2 in von Hippel-Lindauassociated renal cell carcinoma. Mol Cell Biol 2005;25(13):5675-86.

62. Germain S, Monnot C, Muller L, Eichmann A. Hypoxia-driven angiogenesis: role of tip cells and extracellular matrix scaffolding. Curr Opin Hematol 2010;17(3):245-51.

63. Rankin EB, Biju MP, Liu Q, Unger TL, Rha J, Johnson RS, Simon MC, Keith B, Haase VH. Hypoxia-inducible factor-2 (HIF-2) regulates hepatic erythropoietin in vivo. J Clin Invest 2007;117(4):1068-77.

64. Scortegagna M, Morris MA, Oktay Y, Bennett M, Garcia JA. The HIF family member EPAS1/HIF-2alpha is required for normal hematopoiesis in mice. Blood 2003;102(5):1634-40.

65. Scortegagna M, Ding K, Zhang Q, Oktay Y, Bennett MJ, Bennett M, Shelton JM, Richardson JA, Moe O, Garcia JA. HIF-2alpha regulates murine hematopoietic development in an erythropoietin-dependent manner. Blood 2005;105(8):3133-40.

66. Mastrogiannaki M, Matak $P$, Keith $B$, Simon MC, Vaulont $S$, Peyssonnaux C. HIF-2alpha, but not HIF-1alpha, promotes iron absorption in mice. J Clin Invest 2009;119(5):1159-66.

67. Torti SV, Torti FM. Iron and cancer: more ore to be mined. Nat Rev Cancer 2013;13(5):342-55.

68. Chazaud B, Ricoux R, Christov C, Plonquet A, Gherardi RK, BarlovatzMeimon G. Promigratory effect of plasminogen activator inhibitor-1 on invasive breast cancer cell populations. Am J Pathol 2002;160(1):237-46.

69. Skuli N, Majmundar AJ, Krock BL, Mesquita RC, Mathew LK, Quinn ZL, Runge A, Liu L, Kim MN, Liang J, Schenkel S, Yodh AG, Keith B, Simon MC. Endothelial HIF-2alpha regulates murine pathological angiogenesis and revascularization processes. J Clin Invest 2012;122(4):1427-43.

70. Tang $X$, Mo C, Wang Y, Wei D, Xiao H. Anti-tumour strategies aiming to target tumour-associated macrophages. Immunology 2013;138(2):93-104.

71. Vanharanta S, Shu W, Brenet F, Hakimi AA, Heguy A, Viale A, Reuter VE, Hsieh JJ, Scandura JM, Massague J. Epigenetic expansion of VHLHIF signal output drives multiorgan metastasis in renal cancer. Nat Med 2013;19(1):50-6.

72. Wang $X$, Schneider A. HIF-2alpha-mediated activation of the epidermal growth factor receptor potentiates head and neck cancer cel migration in response to hypoxia. Carcinogenesis 2010;31(7):120210.

73. Taieb D, Yang C, Delenne B, Zhuang Z, Barlier A, Sebag F, Pacak K. First report of bilateral pheochromocytoma in the clinical spectrum of HIF2A-related polycythemia-paraganglioma syndrome. J Clin Endocrinol Metab 2013; 98(5):E908-13.
74. Yang C, Sun MG, Matro J, Huynh TT, Rahimpour S, Prchal JT, Lechan R, Lonser R, Pacak K, Zhuang Z. Novel HIF2A mutations disrupt oxygen sensing, leading to polycythemia, paragangliomas, and somatostatinomas. Blood 2013;121(13):2563-6.

75. Lorenzo FR, Yang C, Ng Tang Fui M, Vankayalapati H, Zhuang Z, Huynh T, Grossmann M, Pacak K, Prchal JT. A novel EPAS1/HIF2A germline mutation in a congenital polycythemia with paraganglioma. J Mol Med (Berl) 2013;91(4):507-12.

76. Favier J, Buffet A, Gimenez-Roqueplo AP. HIF2A mutations in paraganglioma with polycythemia. N Engl J Med 2012;367(22):2161; author reply 2161-2.

77. Comino-Mendez I, de Cubas AA, Bernal C, Alvarez-Escola C, SanchezMalo C, Ramirez-Tortosa CL, Pedrinaci S, Rapizzi E, Ercolino T, Bernini G, Bacca A, Leton R, Pita G, Alonso MR, Leandro-Garcia LJ, Gomez-Grana A, Inglada-Perez L, Mancikova V, Rodriguez-Antona C, Mannelli M, Robledo M, Cascon A. Tumoral EPAS1 (HIF2A) mutations explain sporadic pheochromocytoma and paraganglioma in the absence of erythrocytosis. Hum Mol Genet 2013;22(11):2169-76.

78. Toledo RA, Qin Y, Srikantan S, Morales NP, Li Q, Deng Y, Kim SW, Pereira MA, Toledo SP, Su X, Aguiar RC, Dahia PL. In vivo and in vitro oncogenic effects of HIF2A mutations in pheochromocytomas and paragangliomas. Endocr Relat Cancer 2013;20(3):349-59.

79. Buffet $A$, Smati $S$, Mansuy L, Menara M, Lebras M, Heymann MF, Simian C, Favier J, Murat A, Cariou B, Gimenez-Roqueplo AP. Mosaicism in HIF2A-related polycythaemia-paraganglioma syndrome. J Clin Endocrinol Metab 2013 Nov 25. [Epub ahead of print] doi: 10.1210/jc.2013-2600

80. Tian H, Hammer RE, Matsumoto AM, Russell DW, McKnight SL. The hypoxia-responsive transcription factor EPAS1 is essential for catecholamine homeostasis and protection against heart failure during embryonic development. Genes Dev 1998;12(21):3320-4.

81. Jain S, Maltepe E, Lu MM, Simon C, Bradfield CA. Expression of ARNT, ARNT2, HIF1 alpha, HIF2 alpha and Ah receptor mRNAs in the developing mouse. Mech Dev 1998;73(1):117-23.

82. Nilsson H, Jogi A, Beckman S, Harris AL, Poellinger L, Pahlman S. HIF-2alpha expression in human fetal paraganglia and neuroblastoma: relation to sympathetic differentiation, glucose deficiency, and hypoxia. Exp Cell Res 2005;303(2):447-56.

83. Percy MJ, Beer PA, Campbell G, Dekker AW, Green AR, Oscier D, Rainey MG, van Wijk R, Wood M, Lappin TR, McMullin MF, Lee FS. Novel exon 12 mutations in the HIF2A gene associated with erythrocytosis. Blood 2008;111(11):5400-2.

84. Ladroue C, Carcenac R, Leporrier M, Gad S, Le Hello C, Galateau-Salle F, Feunteun J, Pouyssegur J, Richard S, Gardie B. PHD2 mutation and congenital erythrocytosis with paraganglioma. N Engl J Med 2008;359(25):2685-92.

85. Capodimonti S, Teofili L, Martini M, Cenci T, lachininoto MG, Nuzzolo ER, Bianchi M, Murdolo M, Leone G, Larocca LM. Von hippel-lindau disease and erythrocytosis. J Clin Oncol 2012;30(13):e137-9.

86. Eisenhofer G, Huynh TT, Pacak K, Brouwers FM, Walther MM, Linehan WM, Munson PJ, Mannelli M, Goldstein DS, Elkahloun AG. Distinct gene expression profiles in norepinephrine- and epinephrine-producing hereditary and sporadic pheochromocytomas: activation of hypoxia-driven angiogenic pathways in von Hippel-Lindau syndrome. Endocr Relat Cancer 2004;11(4):897-911.

87. Briere JJ, Favier J, Benit P, El Ghouzzi V, Lorenzato A, Rabier D, Di Renzo MF, Gimenez-Roqueplo AP, Rustin P. Mitochondrial succinate is instrumental for HIF1alpha nuclear translocation in SDHAmutant fibroblasts under normoxic conditions. Hum Mol Genet 2005;14(21):3263-9.

88. Dahia PL, Ross KN, Wright ME, Hayashida CY, Santagata S, Barontini M, Kung AL, Sanso G, Powers JF, Tischler AS, Hodin R, Heitritter S, Moore F, Dluhy R, Sosa JA, Ocal IT, Benn DE, Marsh DJ, Robinson BG, Schneider K, Garber J, Arum SM, Korbonits M, Grossman A, Pigny P, Toledo SP, Nose V, Li C, Stiles CD. A HIF1alpha regulatory loop links hypoxia and mitochondrial signals in pheochromocytomas. PLoS Genet 2005;1(1):72-80.

89. Dahia PL. Transcription association of VHL and SDH mutations link hypoxia and oxidoreductase signals in pheochromocytomas. Ann NY Acad Sci 2006;1073:208-20.

90. Favier J, Gimenez-Roqueplo AP. Pheochromocytomas: The (pseudo)-hypoxia hypothesis. Best Pract Res Clin Endocrinol Metab 2010;24(6):957-68.

91. Gimenez-Roqueplo AP, Favier J, Rustin P, Mourad JJ, Plouin PF, Corvol $P$, Rotig A, Jeunemaitre $X$. The R22X mutation of the SDHD gene 
in hereditary paraganglioma abolishes the enzymatic activity of complex II in the mitochondrial respiratory chain and activates the hypoxia pathway. Am J Hum Genet 2001;69(6):1186-97.

92. Gimenez-Roqueplo AP, Favier J, Rustin P, Rieubland C, Kerlan V, Plouin PF, Rotig A, Jeunemaitre $X$. Functional consequences of a SDHB gene mutation in an apparently sporadic pheochromocytoma. J Clin Endocrinol Metab 2002;87(10):4771-4.

93. Pollard PJ, Briere JJ, Alam NA, Barwell J, Barclay E, Wortham NC, Hunt T, Mitchell M, Olpin S, Moat SJ, Hargreaves IP, Heales SJ, Chung YL, Griffiths JR, Dalgleish A, McGrath JA, Gleeson MJ, Hodgson SV, Poulsom R, Rustin P, Tomlinson IP. Accumulation of Krebs cycle intermediates and over-expression of HIF1alpha in tumours which result from germline $\mathrm{FH}$ and $\mathrm{SDH}$ mutations. Hum Mol Genet 2005;14(15):2231-9.

94. Pollard PJ, El-Bahrawy M, Poulsom R, Elia G, Killick P, Kelly G, Hunt T, Jeffery R, Seedhar P, Barwell J, Latif F, Gleeson MJ, Hodgson SV, Stamp GW, Tomlinson IP, Maher ER. Expression of HIF-1alpha, HIF-2alpha (EPAS1), and their target genes in paraganglioma and pheochromocytoma with VHL and SDH mutations. J Clin Endocrinol Metab 2006;91(11):4593-8.

95. Selak MA, Armour SM, MacKenzie ED, Boulahbel H, Watson DG, Mansfield KD, Pan Y, Simon MC, Thompson CB, Gottlieb E. Succinate links TCA cycle dysfunction to oncogenesis by inhibiting HIF-alpha prolyl hydroxylase. Cancer Cell 2005;7(1):77-85.

96. Liu XW, Cai TY, Zhu H, Cao J, Su Y, Hu YZ, He QJ, Yang B. Q6, a novel hypoxia-targeted drug, regulates hypoxia-inducible factor signaling via an autophagy-dependent mechanism in hepatocellular carcinoma. Autophagy 2014;10(1):1-12. [Epub ahead of print]

97. Melillo G. Targeting hypoxia cell signaling for cancer therapy. Cancer Metastasis Rev 2007;26(2):341-52.

98. Melillo G. Hypoxia-inducible factor 1 inhibitors. Methods Enzymol 2007:435:385-402.

99. Scheuermann TH, Li Q, Ma HW, Key J, Zhang L, Chen R, Garcia JA, Naidoo J, Longgood J, Frantz DE, Tambar UK, Gardner KH, Bruick RK. Allosteric inhibition of hypoxia inducible factor- 2 with small molecules. Nat Chem Biol 2013;9(4):271-6.

100. Rogers JL, Bayeh L, Scheuermann TH, Longgood J, Key J, Naidoo J, Melito L, Shokri C, Frantz DE, Bruick RK, Gardner KH, Macmillan JB, Tambar UK. Development of Inhibitors of the PAS-B Domain of the HIF-2alpha Transcription Factor. J Med Chem 2013;56(4):1739-47. 